\title{
PALEOEARTHQUAKES AS ANCHOR POINTS IN BAYESIAN RADIOCARBON DEPOSITION MODELS: A CASE STUDY FROM THE DEAD SEA
}

\author{
Elisa J Kagan ${ }^{1,2,3} \bullet$ Mordechai Stein ${ }^{2} \cdot$ Amotz Agnon $^{1} \bullet$ Christopher Bronk Ramsey $^{4}$
}

ABSTRACT. The Bayesian statistical method of the OxCal v 4.1 program is used to construct an age-depth model for a set of accelerator mass spectrometry (AMS) radiocarbon ages of organic debris collected from a late Holocene Dead Sea stratigraphic section (the Ein Feshkha Nature Reserve). The model is tested for a case where no prior earthquake information is applied and for a case where there is incorporation of known ages of 4 prominent historical earthquakes as chronological anchor points along the section. While the anchor-based model provided a tightly constrained age-depth regression, the "nonanchored" model still produces a correlation where most of the $68 \%$ or $95 \%$ age ranges of the 52 seismites can be correlated to historical earthquakes. This presents us with the opportunity for high-resolution paleoseismic analysis and comparison between various sites.

\section{INTRODUCTION}

Radiocarbon dating of terrestrial organic debris (assumed to have formed under atmospheric equilibrium) is a major tool for establishing chronologies of late Pleistocene and Holocene sedimentary sections for paleoseismology studies (Ken-Tor et al. 2001; Migowski et al. 2004; Lienkaemper and Bronk Ramsey 2009, and references therein). With the development of the Northern Hemisphere ${ }^{14} \mathrm{C}$ calibration curve (Reimer et al. 2004), it is possible to determine accurate ages with a precision of typically around 100-300 yr (95\%) for single measurements for Holocene samples. However, in many cases, the determination of accurate chronology of a sedimentary sequence is hampered by lack of material for dating, recycling of the organic debris, diagenesis, hiatuses, and other factors (examples from the Dead Sea basin: Ken-Tor et al. 2001; Migowski et al. 2004; Neumann et al. 2007). These problems are partly eliminated by the construction of age-depth models that apply uniform sedimentation rates (linear regressions) for the studied sections. For more complex sedimentation patterns and to incorporate typical ${ }^{14} \mathrm{C}$ asymmetrical uncertainties, Bayesian techniques are useful when they also integrate prior information within the age-depth models (e.g. Bronk Ramsey 2008). Prior information could comprise known ages of specific stratigraphic horizons in the studied section, textural composition of the sediments, changes in sedimentary facies, depositional boundaries, and others (see below). Here, we present a case study from the Dead Sea basin where we use historical earthquakes correlated with disturbed layers as prior-information anchors in an age-depth deposition model to improve and better constrain the regression-age model. This model will be used to retrieve a high-resolution paleoseismic record of the seismically active Dead Sea Transform area.

\section{BAYESIAN AGE-DEPTH MODELING}

The mathematical details of Bayesian modeling are explained in detail in the literature (e.g. Buck et al. 1991; D'Agostini 2003; Bronk Ramsey 2008). The approach taken in this paper and the explanations here are largely based on what is laid out in Bronk Ramsey (2008) and Blockley et al. (2008). The age models for the Ein Feshkha site were built using the ${ }^{14} \mathrm{C}$ calibration software OxCal v 4.1 (Bronk Ramsey 1995, 2001), and key terms will be explained here. Bayesian analysis uses prior information and suppositions when generating a model from any data set. This incorporation is usually termed the prior. The fundamental assumption in Bayesian modeling of stratigraphic sequences

\footnotetext{
${ }^{1}$ Institute of Earth Sciences, Hebrew University of Jerusalem, Givat Ram, Jerusalem 91904, Israel.

${ }^{2}$ Geological Survey of Israel, 30 Malkhe Israel, Jerusalem 95501, Israel.

${ }^{3}$ Corresponding author. Email: elisa.kagan@mail.huji.ac.il.

${ }^{4}$ Research Laboratory for Archaeology \& the History of Art, University of Oxford, Oxford, United Kingdom.
}

(C) 2010 by the Arizona Board of Regents on behalf of the University of Arizona Proceedings of the 20th International Radiocarbon Conference, edited by A J T Jull RADIOCARBON, Vol 52, Nr 2-3, 2010, p 1018-1026 
is that age increases with depth. This prior requires use of a function usually termed Boundaries. These boundaries separate different sedimentary units that may have different sedimentation rates, grain sizes, and facies. They are also placed on the top and bottom of the entire series to constrain the model to a specific timeframe. With no other information, this would be treated by what is usually termed the Sequence model. A uniform sedimentation rate would be treated with the $U$ Sequence type model. Depth and other dating information can be included in a less rigid way using Poisson distribution priors, termed $P_{-}$Sequence models, where the time gap between deposition of grains varies, and the events are basically random; however, deposition is given approximate proportionality to depth. This entails the estimation of the uniformity of the deposition (given as the $k$ parameter), which indicates the increment size (conceptually the grain size, or size of deposition events) and signifies the relationship between the events and the stratigraphic process.

All events in the sequence and therefore in the model are related to stratigraphic depths. The stages of modeling are as follows:

- Evaluate the sedimentary sequence, noting any depths where deposition characteristics clearly change.

- Identify the depths at which there are any obvious signs of earthquake activity in the sequence (appearance of seismites).

- ${ }^{14} \mathrm{C}$ date samples through the sequence at specific depths. This provides constraints on the timing of deposition.

- Evaluate the expected uniformity of deposition. For example, if there is sediment of $100 \mathrm{~cm}$ thickness and the dates of the top and bottom of this sequence are known, with what uncertainty can you say that the point half-way down was deposited at the midpoint in time between the top and bottom? In this case, for a 5\% uncertainty in this model (approximately Normally distributed), we choose a $k$ value of $1 \mathrm{~cm}^{-1}$, which corresponds to a nominal event size of $1 \mathrm{~cm}$.

- Construct an age-depth model with Boundaries at the top, bottom, and at any depths where there is likely to have been a major deposition change.

- Decide at what resolution you need to interpolate the age-depth model. For an interpolation rate of 1 every $10 \mathrm{~cm}$ (or $0.1 / \mathrm{cm}$ ), we use an interpolation parameter of 0.1 , so in this case the model is set up with the $P$ _Sequence command: P_Sequence("“",1,0.1);

- Run the age-depth model with the ${ }^{14} \mathrm{C}$ dating information as the only time control.

- Interpolate between the ${ }^{14} \mathrm{C}$-dated points using the model, to determine a first estimate for the dates of each of the identified horizons.

- Decide whether any of the observed seismites can be confidently assigned to historically documented and dated earthquakes. If so, this information can be added to the model as anchors, and the model run again including this additional information.

- Interpolate between the ages and boundaries defined in the model to get final date probability distributions and ranges for all earthquake depths in the sequence.

As with any Bayesian model, the results of the analysis are dependent on the data that have been included and on all of the prior information supplied and assumptions that have been made. A comparison of the unanchored and anchored distributions (as shown in Figure 5) shows the degree to which the prior knowledge of the historical earthquake impacts on the model output (or posterior). It is also important to remember that the rigidity of the deposition model (as defined above and shown clearly in the interpolation between points in the right panel of Figure 5) is defined by the model and not by the data. 


\section{EIN FESHKHA SECTION OF NORTHERN DEAD SEA BASIN AND ITS PALEOSEISMIC RECORD}

The sediments of the Holocene Dead Sea compose the Ze'elim Formation of the Dead Sea Group. This sedimentary sequence has been deposited within the Dead Sea rift valley that formed by slip along the Dead Sea Transform, an active tectonic boundary between the Arabian plate and the Sinai subplate (Figure 1). Destructive earthquakes occurring in the area during the past 4 millennia have been documented in catalogs (i.e. Ben-Menahem 1991; Ambraseys et al. 1994; Amiran et al. 1994; Guidoboni et al. 1994; Guidoboni and Comastri 2005). The sediments represent various depositional environments: fluvial, fan deltas, shores, and lacustrine (see detailed description in Bookman [Ken-Tor] et al. 2004; Bookman et al. 2006). The mainly anthropogenic decrease of the current lake level $(\sim 100 \mathrm{~cm} / \mathrm{yr})$ has triggered deep incisions along the retreating shores. These incised gullies have provided excellent opportunities to study the late Holocene sedimentary sections in detail. At the Ein Feshkha Nature Reserve (Figure 1), new gullies were formed recently exposing the late Holocene section (spanning 4000 to $600 \mathrm{yr}$ BP; Neumann et al. 2007). The outcrop exposes the laminated lacustrine marls (mainly calcitic silts and clays) and sequences of laminated primary aragonite and fine detritus. Fifty-two layers in this normally laminated sequence display disturbed sedimentary features (Figure 2; details of the seismite sedimentary features are given in Kagan et al., forthcoming). Based on previous studies of similar disturbed layers (Marco et al. 1996; Ken-Tor et

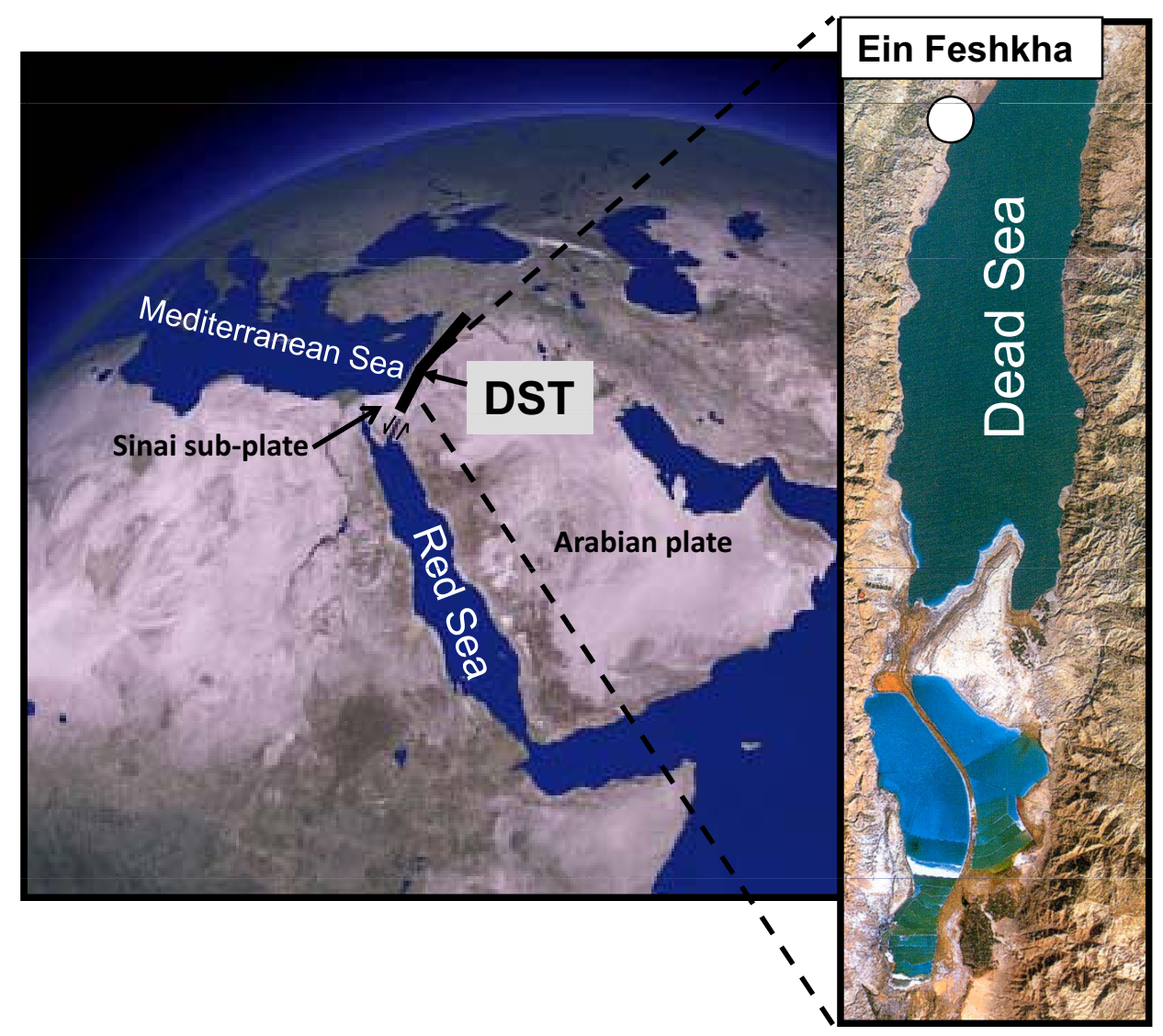

Figure 1 Satellite image of Dead Sea Transform (DST) (red line) with zoom in (right) to the Dead Sea. The white circle indicates Ein Feshkha gully site. 
al. 2001; Migowski et al. 2004), it was proposed that the disturbed layers represent earthquake markers and thus are termed "seismites." The appearance of multiple types of seismites in the sedimentary section as well as the availability of numerous ${ }^{14} \mathrm{C}$-datable organic debris afford the opportunity to retrieve a high-resolution paleoseismic record of this seismically active area. This record can be integrated with the chronology of historical earthquakes available for this region. At the same time, the best-known historical earthquakes can be used as anchors in Bayesian models to improve the ${ }^{14} \mathrm{C}$ chronology of the studied section.
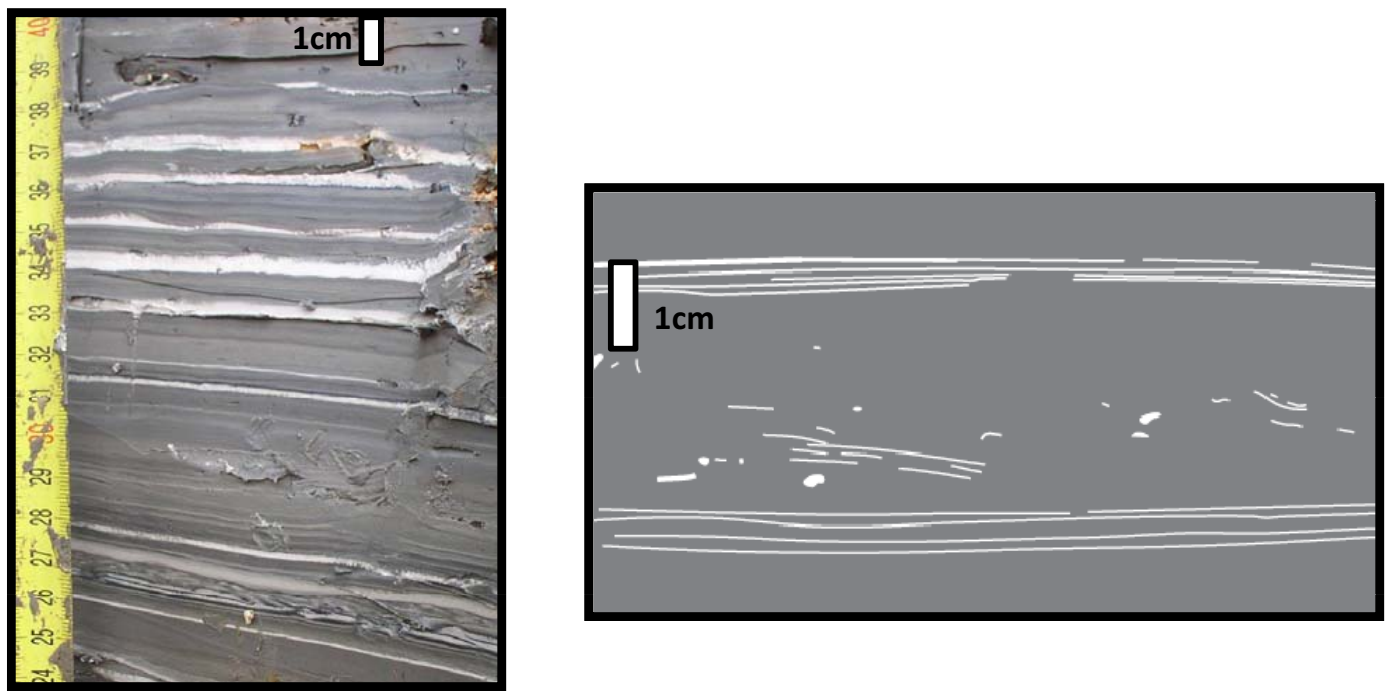

Figure 2 Left: Ein Feshkha gully wall outcrop showing sequences of laminated primary aragonite and fine detritus. Right: Schematic diagram of brecciated laminae. Fragmented laminae are "floating" in dark matrix.

\section{${ }^{14} \mathrm{C}$ DATING OF THE SECTION AND INTRODUCTION OF BAYESIAN MODELING}

The chronology of the Ein Feshkha (EFE) section is constructed by ${ }^{14} \mathrm{C}$ dating of terrestrial organic debris (mainly small pieces of wood and twigs). Six samples from the outcrop were prepared for ${ }^{14} \mathrm{C}$ dating at the ${ }^{14} \mathrm{C}$ laboratory at the Weizmann Institute, Rehovot, Israel (see Neumann et al. 2007). The samples were then measured by accelerator mass spectrometry (AMS) at the $\mathrm{NSF}^{14} \mathrm{C}$ facility at the University of Arizona. Four additional organic debris samples were taken from a correlated drilled core located on the cliff bounding the gully (only a few meters away) and were analyzed at the AMS facility in Kiel. The core was correlated with the outcrop by Marcus Schwab at GFZ-Potsdam based on high-resolution stratigraphic correlation of sedimentary markers, which included unusually thick aragonite laminae, aragonite-clay laminated sequences, and deformed layers, and was aided by the unmodeled calibrated ${ }^{14} \mathrm{C}$ dates. ${ }^{14} \mathrm{C}$ ages are reported (Table 1 ) in conventional ${ }^{14} \mathrm{C}$ years (before present $=1950$ ) in accordance with international convention (Stuiver and Polach 1977). Calibrated ages (cal BP) were calculated by applying the IntCal04 calibration data (Reimer et al. 2004) by means of the OxCal v. 4.1 program (Bronk Ramsey 1995, 2001, 2008) (Figure 4).

The age-depth models that incorporate Bayesian modeling are constructed in several steps that are illustrated schematically in the flow chart of Figure 3. The ${ }^{14} \mathrm{C}$ ages (listed in Table 1) are treated by a simple Bayesian $P$ _Sequence deposition model. The model applies a $k$ factor of 1 (which implies for the midpoint of a 1-m section a 5\% uncertainty in interpolation, see Bronk Ramsey 2008: Equa- 
Table $1{ }^{14} \mathrm{C}$ dates of organic debris from the Ein Feshkha lacustrine outcrop and core. Depths of prominent earthquakes used as anchors are shown in italics along with the historical dates of these events.

\begin{tabular}{llllll}
\hline Sample nr & Lab nr & $\begin{array}{l}\text { Depth below } \\
\text { surface }(\mathrm{cm})\end{array}$ & $\begin{array}{l}{ }^{14} \mathrm{C} \text { yr } \\
(\mathrm{BP})\end{array}$ & $\begin{array}{l}\text { Calibrated age } \\
\text { range }(1 \sigma)\end{array}$ & $\begin{array}{l}\text { Calibrated age } \\
\text { range }(2 \sigma)\end{array}$ \\
\hline EFW-009 & RTT5174 & 9 & $700 \pm 40$ & AD 1269-1382 & AD 1243-1392 \\
Anchor & & 28 & & $\begin{array}{l}A D ~ 1212 \\
\end{array}$ & \\
EFW-029 & RTT5175 & 29 & $780 \pm 40$ & AD 1223-1271 & AD 1179-1285 \\
DSF-B1-31 & KIA32722 & 46.5 & $933 \pm 36$ & AD 1039-1155 & AD 1022-1183 \\
EFW-80 & RTT5176 & 80 & $1015 \pm 40$ & AD 980-1117 & AD 899-1155 \\
EFW-120 & RTT5177 & 120 & $1310 \pm 40$ & AD 661-768 & AD 648-779 \\
Anchor & & 125 & & $A D$ 757 & \\
Anchor & & 210 & & $A D 419$ & \\
DSF B3-28 & KIA11641 & 218.5 & $1541 \pm 68$ & AD 432-576 & AD 392-646 \\
Anchor & & 338 & & 31 BC & \\
DSF-B5-43 & KIA11642 & 412 & $2143 \pm 27$ & $345-113$ BC & $351-59$ BC \\
DSF-B5-58 & KIA32723 & 426.5 & $2215 \pm 29$ & $359-207 \mathrm{BC}$ & $376-201$ BC \\
EFW-430 & RTT5180 & 430 & $2150 \pm 45$ & $350-110 \mathrm{BC}$ & $359-52 \mathrm{BC}$ \\
EFW-492 & RTT5181 & 492 & $2380 \pm 40$ & $510-396 \mathrm{BC}$ & $741-385 \mathrm{BC}$ \\
\hline
\end{tabular}

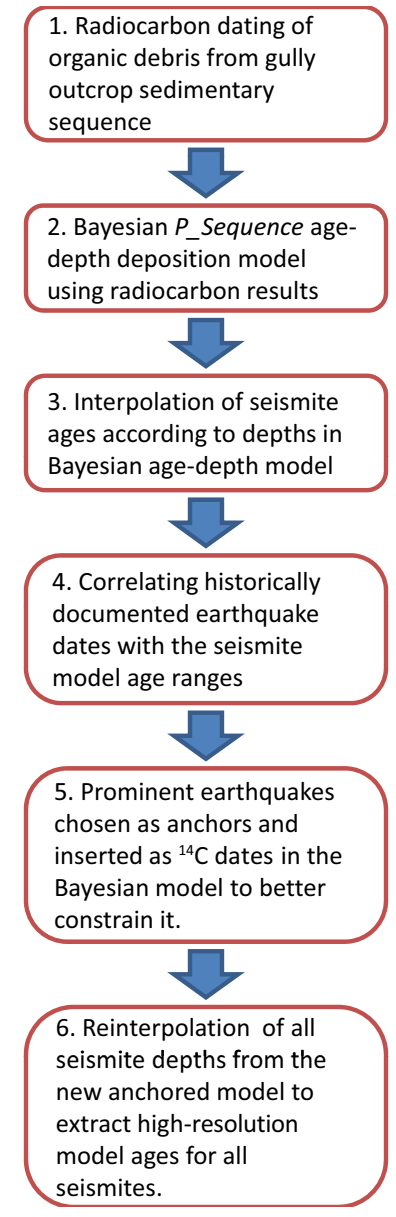

Figure 3 Flowchart describing steps in Bayesian age-depth modeling of paleoseismic record with earthquake anchors. 
tion 17A) (Figure 5, left panel). The next step embodies the interpolation of seismite ages using the OxCal v 4.1 program and the Bayesian model. This results in a model age range for each seismite depth (not shown). We then correlate the historically documented earthquake dates with the seismite model age ranges. This procedure is analogous to floating chronology matching, where the entire sequence of historical earthquakes is matched to the sequence of model ages of seismites from the section (e.g. Migowski et al. 2004). However, in this case both data sets are time constrained, the historical record has negligible uncertainty in the ages of the earthquakes in the past 2 millennia, and the seismite age uncertainties are given by the model age ranges. Relative historically documented intensities, interseismic intervals, and other seismicity parameters are taken into consideration when various historical earthquakes can be fit to the same seismites. Then, prominent earthquakes in the historical record were selected as anchor points. These anchors were inserted into the OxCal v 4.1 model code as specific calendar ages (function termed C_Date). We then reiterate the model using the anchors (Figure 5, right panel). In the final step, we can reinterpolate all seismite depths from the new anchored model to extract high-resolution model ages for all seismites.

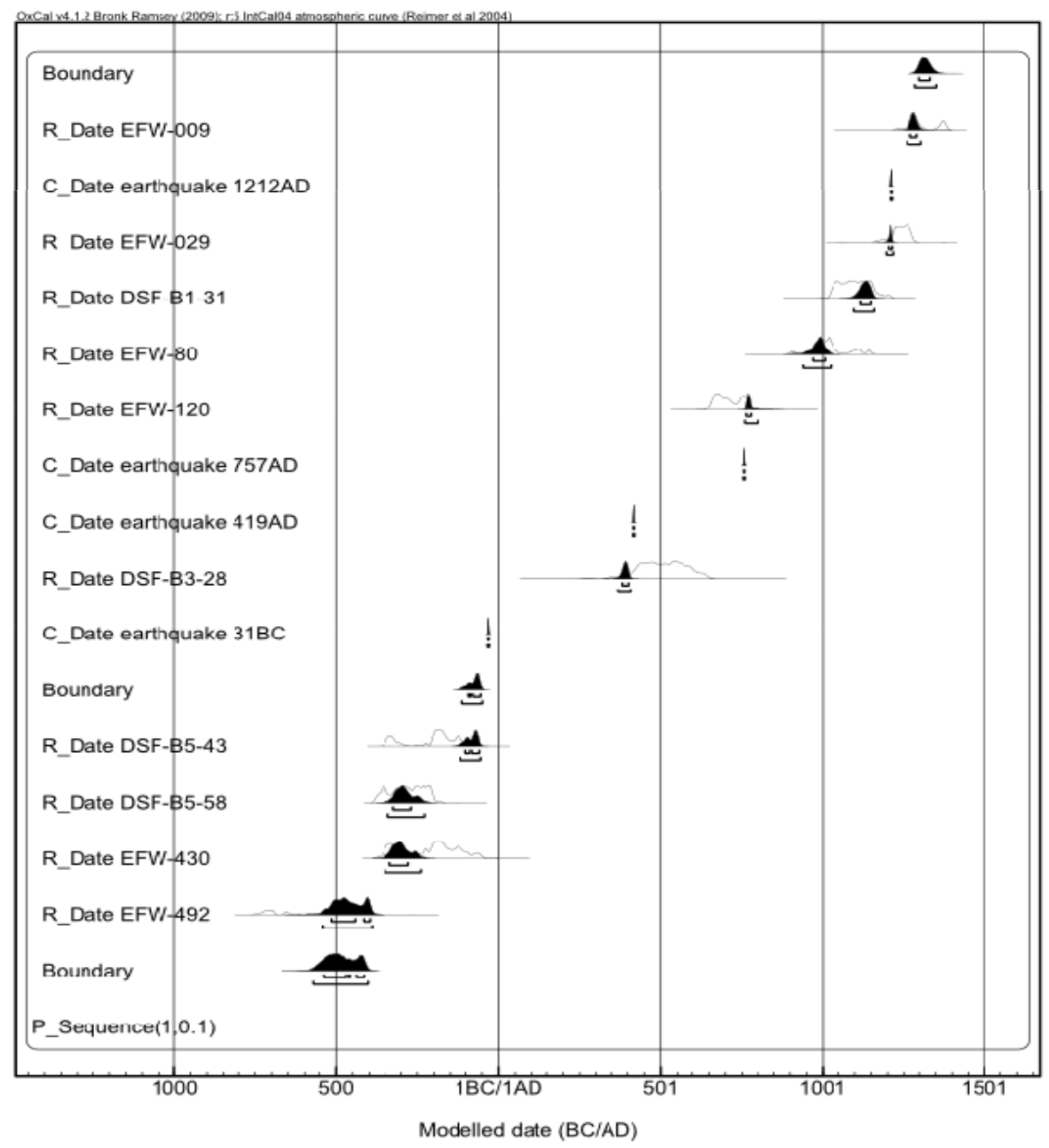

Figure 4 Date distribution of calibrated ${ }^{14} \mathrm{C}$ ages 


\section{INCORPORATION OF EARTHQUAKE ANCHORS TO THE BAYESIAN MODEL}

Fifty-two ages of seismite horizons were interpolated from the non-anchored Bayesian model of the Ein Feshkha outcrop that is presented in Figure 5, left panel. The calendar age of each seismite is limited by the model age range interpolated from the non-anchored model. The chronology of historical earthquakes (i.e. Ben-Menahem 1991; Ambraseys et al. 1994; Amiran et al. 1994; Guidoboni et al. 1994; Guidoboni and Comastri 2005) was then matched to the non-anchored Bayesian model of the Ein Feshkha section.

Four seismite ages were selected according to the following criteria: 1) their historical match represents prominent earthquakes in the historical catalogues; 2) they are identified in other sections of the Dead Sea basin (Ken-Tor et al. 2001; Migowski et al. 2004); 3) they are very close to ${ }^{14} \mathrm{C}$ age samples; and 4) the matched historical earthquake falls well inside the model age range and does not fall into any of the other possible model ages for such events. The anchors chosen are: AD 1212, $\mathrm{AD} 757, \mathrm{AD} 419$, and $31 \mathrm{BC}$. These anchors were inserted into the OxCal model code as calendar ages $\left(C_{-}\right.$Date). We then ran the OxCal model again using the anchors (Figure 5, right panel). The code for the OxCal model with anchors is given in the Appendix.

\section{Bayesian age-depth model (unanchored)}

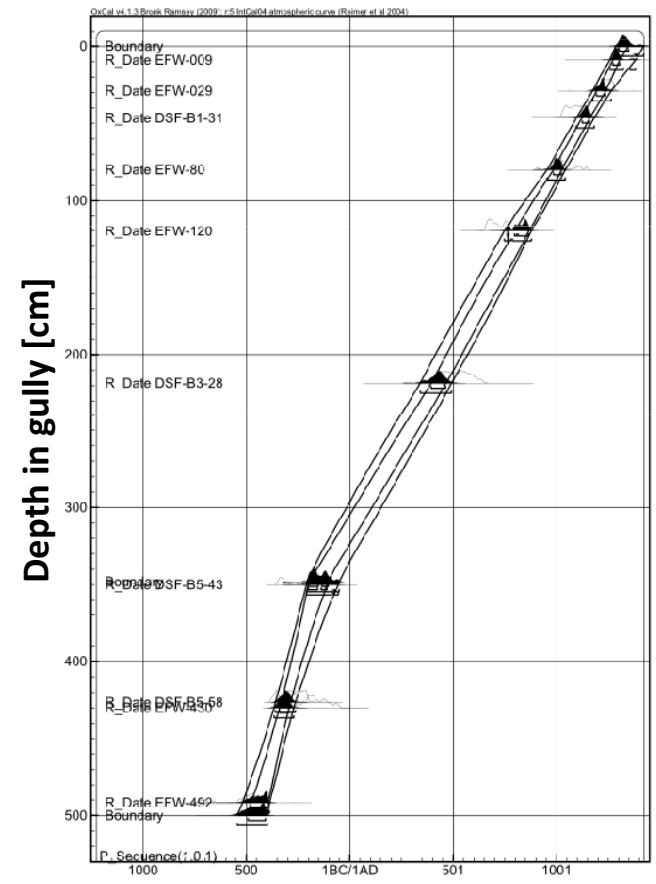

Modeled Age (BC/AD)

\section{Bayesian age-depth model (4 earthquake anchors)}

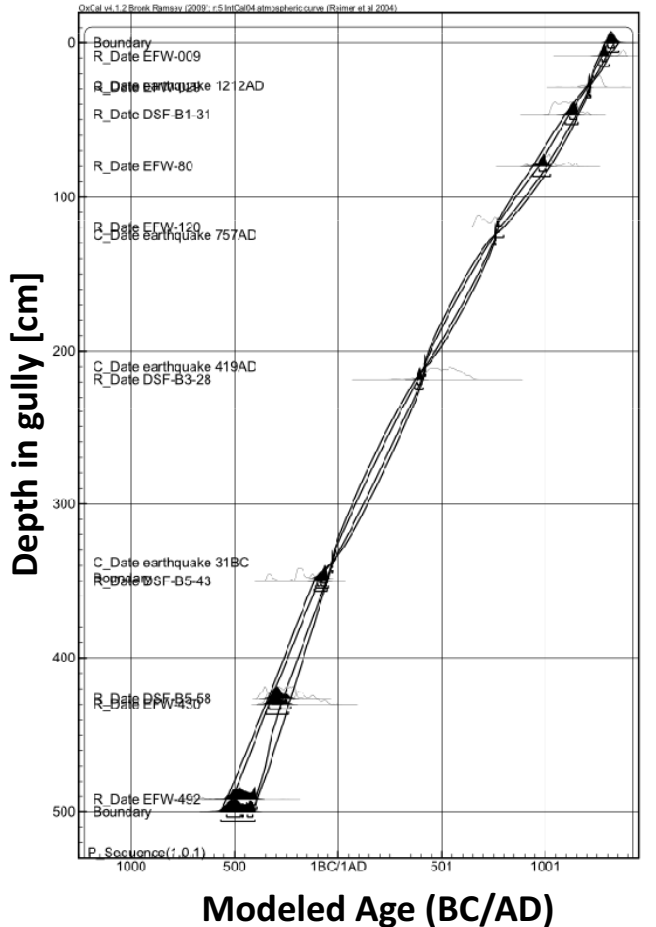

Figure 5 Bayesian $P$ Sequence age-depth models for the top $5 \mathrm{~m}$ of the Ein Feshkha gully exposure. Left: OxCal age-depth model using 10 radiocarbon ages $\left(R \_\right.$Date $)$. Right: age-depth model using 10 radiocarbon ages $\left(R \_\right.$Date $)$and 4 historical earthquake dates used as anchors $\left(C_{-}\right.$Date $)$. 


\section{CONCLUSIONS}

The Bayesian statistical method of the OxCal v 4.1 program is used to construct an age-depth model for a set of AMS ${ }^{14} \mathrm{C}$ ages of organic debris collected from a late Holocene Dead Sea stratigraphic section (the Ein Feshkha Nature Reserve). This paper tests the benefits of constraining the model to prior historical earthquake information, in this case, ages of several prominent historical earthquakes that occurred in the studied area. The anchor-based model provided a tightly constrained age-depth regression. However, the "non-anchored" model as well produces a seismite/historicalearthquake correlation where all of the $68 \%$ or $95 \%$ age ranges of the seismites can be correlated to historical earthquakes. We prefer the unanchored model, being almost as well constrained as the anchored model, for paleoseismic studies in this section. This preference is in view of complexities involved in correlating seismites (including historical inconsistencies), well dated as they may be, to specific historical earthquakes.

The procedure developed here opens the way for establishing a high-resolution and accurate chronology for paleoearthquake records of the Dead Sea basin, and possibly other locations where prior and independent (paleoseismic) information can be incorporated with the ${ }^{14} \mathrm{C}$ dating of the sedimentary section.

\section{ACKNOWLEDGMENTS}

We would like to thank Frank Neumann for help in the field and laboratory, Markus Schwab for core-outcrop correlation, and Elisabetta Boaretto for preparation of ${ }^{14} \mathrm{C}$ samples at the Rehovot facility. This research was supported by the German-Israel Foundation (GIF) for science and development, contract I-805.221.8/2003 granted to A Agnon and M Stein.

\section{REFERENCES}

Ambraseys N, Melville CP, Adams RD. 1994. The Seismicity of Egypt, Arabia and the Red Sea. Cambridge: Cambridge University Press. $181 \mathrm{p}$.

Amiran DHK, Arieh E, Turcotte T. 1994. Earthquakes in Israel and adjacent areas: macroseismic observations since 100 B.C.E. Israel Exploration Journal 44:260 305.

Ben-Menahem A. 1991. Four thousand years of seismicity along the Dead Sea Rift. Journal of Geophysical Research 96(B12):20,195-216.

Blockley SPE, Ramsey CB, Lane CS, Lotter AF. 2008. Improved age modelling approaches as exemplified by the revised chronology for the Central European varved lake Soppensee. Quaternary Science Reviews 27(1-2):61-71.

Bookman (Ken-Tor) R, Enzel Y, Agnon A, Stein M. 2004. Late Holocene lake levels of the Dead Sea. Geological Society of America Bulletin 116:555-71.

Bookman R, Bartov Y, Enzel Y, Stein M. 2006. The levels of late Quaternary lakes in the Dead Sea basin: a century of research. In: Enzel Y, Stein M, Agnon A, editors. New Frontiers in the Dead Sea Paleoenvironmental Research. GSA Special Paper 401:155-70.

Bronk Ramsey C. 1995. Radiocarbon calibration and analysis of stratigraphy: the OxCal program. Radiocarbon 37(2):425-30.
Bronk Ramsey C. 2001. Development of the radiocarbon calibration program. Radiocarbon 43(2A):355-63.

Ramsey Bronk C. 2008. Deposition models for chronological records. Quaternary Science Reviews 27(1-2): 42-60.

Buck CE, Kenworthy JB, Litton CD, Smith AFM. 1991. Combining archaeological and radiocarbon information - a Bayesian-approach to calibration. Antiquity 65(249):808-21.

D’Agostini G. 2003. Bayesian inference in processing experimental data: principles and basic applications. Reports on Progress in Physics 66(9):1383-419.

Guidoboni E, Comastri A. 2005. Catalogue of Earthquakes and Tsunamis in the Mediterranean Area from the 11th to the 15th Century. Bologna: Istituto Nazionale di Geofisica e Vulcanologia. 1037 p.

Guidoboni E, Comastri A, Traina G. 1994. Catalogue of Ancient Earthquakes in the Mediterranean Area up to the 10th Century. Bologna: Istituto Nazionale di Geofisica e Vulcanologia. $504 \mathrm{p}$.

Kagan EJ, Stein M, Agnon A, Neumann F. Forthcoming. Intrabasin paleoearthquake correlation of the late Holocene Dead Sea. Journal of Geophysical Research.

Ken-Tor R, Agnon A, Enzel Y, Stein M, Marco S, Negendank JFW. 2001. High-resolution geological record of historic earthquakes in the Dead Sea basin. Journal of 
Geophysical Research 106(B2):2221-34.

Lienkaemper JL, Bronk Ramsey C. 2009. OxCal: versatile tool for developing paleoearthquake chronologies - a primer. Seismological Research Letters 80(3): 431-4.

Marco S, Stein M, Agnon A, Ron H. 1996. Long-term earthquake clustering: a 50,000-year paleoseismic record in the Dead Sea Graben. Journal of Geophysical Research 101(B3):6179-92.

Migowski C, Agnon A, Bookman R, Negendank JFW, Stein M. 2004. Recurrence pattern of Holocene earthquakes along the Dead Sea transform revealed by varve-counting and radiocarbon dating of lacustrine sediments: Earth and Planetary Science Letters 222(1):301-14.
Neumann FH, Kagan EJ, Schwab MJ, Stein M. 2007. Palynology, sedimentology and palaeoecology of the late Holocene Dead Sea. Quaternary Science Reviews 26(11-12):1476-98.

Reimer PJ, Baillie MGL, Bard E, Bayliss A, Beck JW, Bertrand CJH, Blackwell PG, Buck CE, Burr GS, Cutler KB, Damon PE, Edwards RL, Fairbanks RG, Friedrich M, Guilderson TP, Hogg AG, Hughen KA, Kromer B, McCormac G, Manning S, Bronk Ramsey C, Reimer RW, Remmele S, Southon JR, Stuiver M, Talamo S, Taylor FW, van der Plicht J, Weyhenmeyer CE. 2004. IntCal04 terrestrial radiocarbon age calibration, 0-26 cal kyr BP. Radiocarbon 46(3):1029-58.

Stuiver M, Polach HA. 1977. Discussion: reporting of ${ }^{14} \mathrm{C}$ data. Radiocarbon 19(3):355-63.

\section{APPENDIX}

Code for the anchored age-depth OxCal v 4.1 Bayesian deposition model (the unanchored model code is virtually the same but without the $C_{-}$Date entries):

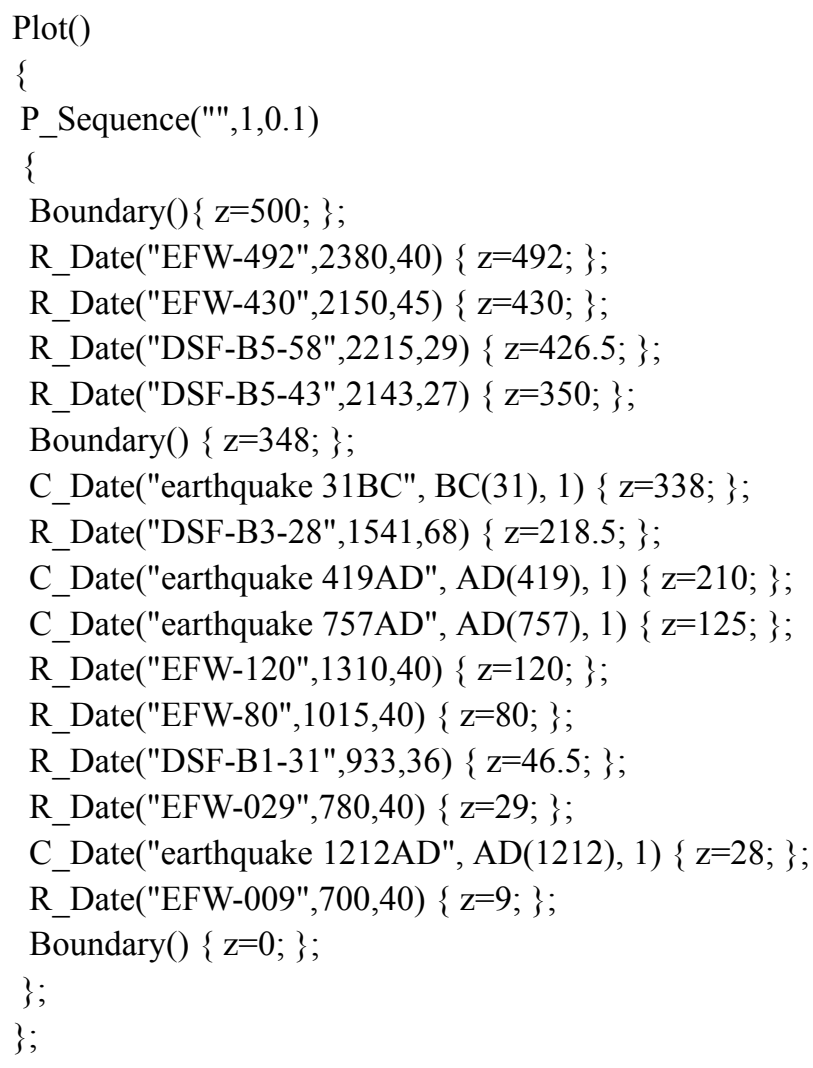

